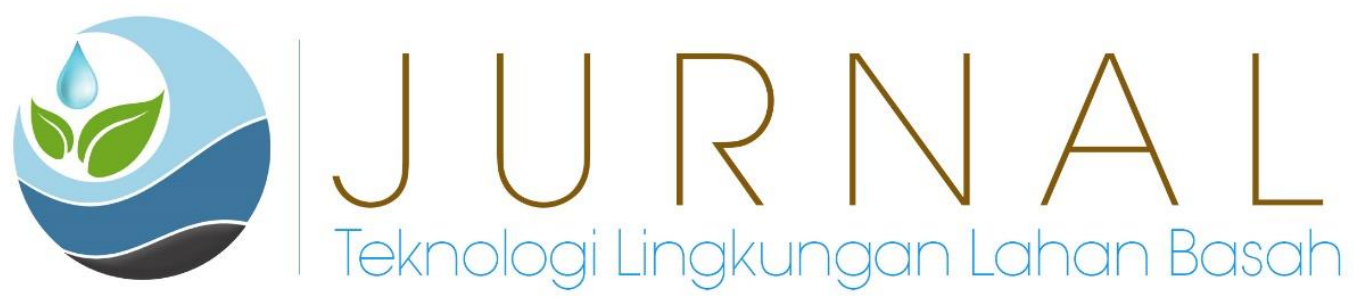

\title{
Pengaruh Konsentrasi NaOH pada Deasetilasi Kitin dari Cangkang Udang Putih (Litopenaeus vannamei) dan Aktivitasnya pada Air Gambut
}

\author{
Syahrul khairi ${ }^{1}$, Pradika Wibowo ${ }^{1}$, Raden Bayu Trisno Wijoyo ${ }^{1}$, Sri Rezeki ${ }^{1}$ \\ ${ }^{1}$ Jurusan Teknik Kimia, Fakultas Teknik, Universitas Tanjungpura, Jln. Prof. Dr. \\ H. Hadari Nawawi, Pontianak, Kalimantan Barat, Indonesia \\ E-mail : syahrul.khairi@untan.ac.id
}

\begin{abstract}
The potential of shrimp shells as a source of chitosan for the processing of West Kalimantan peat water has been studied. Chitin as a precursor of chitosan was extracted from the shrimp shells by means of deproteination and demineralization processes. Deproteination was performed by suspending the shrimp shells to $3,5 \% \mathrm{NaOH}$ at $65^{\circ} \mathrm{C}$ for 4 hours. The demineralization process was done by using $1.5 \mathrm{M} \mathrm{HCl}$ at the same temperature and time. Difference concentration of $\mathrm{NaOH}(30-70 \%)$ was applied in deacetylation of chitin to chitosan in order to obtain informations on the effect of base on chitosan deacetylation degree. The results obtained showed that the higher the concentration of $\mathrm{NaOH}$, the higher the chitosan deacetylation degree. The highest deacetylation degree was obtained when chitin was deacetylation using $70 \% \mathrm{NaOH}$ with the value of $87.5 \%$. Performance of the chitosan was examined in the peat water treatment process. Some test parameters showed that chitosan added to peat water causes coagulation and flocculation with peat water components. This was indicated by the decreasing in color parameter value of $337 \mathrm{PtCo}$, the decreasing of organic substances in peat water of $10 \mathrm{mg} / \mathrm{L}$ and the increasing of $\mathrm{pH}$ value to 7.9.
\end{abstract}

Keywords: chitin, chitosan, coagulation, flocculation, peat water

\begin{abstract}
Abstrak
Potensi cangkang udang putih sebagai sumber kitosan untuk proses pengolahan air gambut Kalimantan Barat telah dipelajari. Kitin sebagai prekursor dari kitosan diekstrak dari kulit udang putih melalui dua tahap yaitu deproteinasi dan demineralisasi. Deproteinasi dilakukan dengan menggunakan NaOH 3,5\% pada suhu $65^{\circ} \mathrm{C}$ selama 4 jam dan dilanjutkan dengan proses demineralisasi menggunakan $\mathrm{HCl}$ 1,5M dengan suhu dan waktu yang sama. Variasi konsentrasi basa NaOH sebesar 30 - $70 \%$ dilakukan pada proses deasetilasi kitin menjadi kitosan guna mendapatkan informasi pengaruh konsentrasi basa terhadap derajat deasetilasi kitosan. Hasil yang diperoleh menunjukkan bahwa semakin tinggi konsentrasi basa $\mathrm{NaOH}$ yang digunakan maka semakin tinggi pula derajat deasetilasi kitosan yang diperoleh. Konversi tertinggi diperoleh ketika kitin dideasetilasi menggunakan $\mathrm{NaOH} 70 \%$ dengan nilai derajat deasetilasi sebesar 87,5\%. Performa kitosan hasil deasetilasi terbaik diuji pada proses pengolahan air gambut. Beberapa parameter uji menunjukkan bahwa kitosan yang ditambahkan pada air gambut menyebabkan terjadinya koagulasi dan flokulasi dengan komponen air gambut. Hal ini ditandai dengan menurunnya nilai parameter warna sebesar 337 PtCo kandungan zat organik di dalam air gambut sebesar $10 \mathrm{mg} / \mathrm{L}$ dan nilai $\mathrm{pH}$ yang meningkat menjadi 7,9.
\end{abstract}

Kata kunci: kitin, kitosan, koagulasi, flokulasi, air gambut 


\section{PENDAHULUAN}

Meningkatnya jumlah penduduk menyebabkan peningkatan kebutuhan air bersih untuk kehidupan sehari-hari. Kualitas air pada setiap daerah di dunia sangat bergantung pada keadaan alam dan kegiatan manusia di daerah tersebut. Di area gambut, umumnya air permukaan yang tersedia sebagai air baku masih sulit dimanfaatkan untuk kebutuhan sehari-hari. Air permukaan daerah tersebut berwarna merah kecoklatan karena mengandung zat organik yang tinggi dan bersifat asam. Kalimantan Barat sendiri merupakan provinsi dengan luas lahan gambut yang besar yaitu $17.299,8 \mathrm{~km}^{2}$ atau sekitar $12 \%$ dari total luas provinsi ini (Wetland International, 2004).

Pengolahan air saat ini banyak menggunakan koagulan berbasis logam aluminium (Al). Tawas dan PAC merupakan contoh dari koagulan berbasis Al yang banyak digunakan. Pada beberapa proses elektrokoagulasi juga masih menggunakan Al sebagai elektroda kerja dan elektroda lawan. $\mathrm{Al}(\mathrm{OH})_{3}$ yang terbentuk dapat berfungsi sebagai koagulan partikel-partikel padatan terlarut dan tersuspensi baik itu organik maupun anorganik. Beberapa kelemahan penggunaan koagulan anorganik ini di antaranya adalah bersifat toksik jika digunakan berlebihan. Pencarian koagulan baru yang ramah lingkungan cukup menarik perhatian banyak peneliti untuk mengatasi permasalahan tersebut.

Kitosan merupakan salah satu polisakarida penting setelah selulosa dan karbohidrat. Dengan banyaknya gugus fungsi kationik pada kitosan, menyebabkan polimer ini berpotensi untuk dikombinasikan dengan senyawa lain dan diaplikasikan di berbagai proses, di antaranya adalah pengolahan limbah bauksit (Bigogno, 2018), adsorpsi boron (Türker, 2017), dan koagulasi senyawa negatif seperti asam humat pada air gambut (Zulfikar, 2014; Santoso, 2015; Ariyani, 2015). Kitosan merupakan turunan utama dari kitin. Kitin sendiri dapat ditemukan secara alamiah di alam pada cangkang hewan-hewan krustasea dan pada dinding sel jamur. Untuk mendapatkan kitosan dengan kualitas baik relatif sangat sulit, menyebabkan penggunaan polisakarida ini relatif jarang. Salah satu indikator kualitas kitosan adalah dengan melihat nilai derajat deasetilasi kitosan tersebut.

Derajat deasetilasi (DD) merupakan suatu nilai yang menggambarkan kualitas suatu kitosan. Semakin tinggi nilai DD menggambarkan semakin banyak gugus fungsi asetil yang terkonversi menjadi amina (Brugnerotto, 2001). Dengan demikian secara umum akan semakin baik kualitas kitosan tersebut. Konversi gugus asetil menjadi amina sangat bergantung pada basa yang digunakan (de Moura, 2011). Penelitian yang dilakukan oleh de Moura pada tahun 2011 mengkonfirmasikan jika basa $\mathrm{NaOH}$ menunjukkan performa lebih baik dari $\mathrm{KOH}$ pada deasetilasi kitin menjadi kitosan dengan derajat deasetilasi mencapai 95,7\%. Selain jenis basa, konsentrasi basa juga memegang peranan penting untuk mendapatkan nilai DD yang optimum. Kajian mengenai pengaruh konsentrasi basa terhadap nilai DD penting untuk dilakukan untuk mendapatkan bagian kondisi operasi yang optimum.

Berdasarkan uraian di atas, maka dalam tulisan ini akan dibahas mengenai pengaruh konsentrasi basa $\mathrm{NaOH}$ pada derajat deasetilasi kitosan dari kitin cangkang udang putih (Litopenaeus vannamei) dan kajian aplikasinya sebagai koagulan senyawa-senyawa humat di air gambut kota Pontianak.

\section{METODE PENELITIAN}

Cangkang udang putih diperoleh dari PT. Pulau Mas Khatulistiwa, yang merupakan salah satu perusahaan pengekspor udang dan ikan di Pontianak, Kalimantan Barat. Limbah kulit udang putih yang telah bersih dan halus, diayak dengan ayakan ukuran 100 mesh. Proses deproteinasi dilakukan dengan mensuspensikan kulit udang putih halus ke dalam 
$\mathrm{NaOH} 3,5 \%$ dengan perbandingan $1: 10(\mathrm{w} / \mathrm{v})$ pada suhu $65^{\circ} \mathrm{C}$ selama 4 jam. Padatan yang tersisa dicuci dan selanjutnya dinetralkan menggunakan aquades sebelum dikeringkan pada suhu $80^{\circ} \mathrm{C}$ selama 24 jam. Kondisi operasi yang sama juga diberlakukan pada proses demineralisasi menggunakan $\mathrm{HCl}$ 1,5M dengan perbandingan 1:15 (w/v).

Variasi konsentrasi $\mathrm{NaOH}$ yaitu sebesar 30, 40, 50, 60 dan 70\% dilakukan pada proses deasetilasi kitin menjadi kitosan. Berdasarkan metode knorr (1982) komposisi suspensi antara kitin dan $\mathrm{HCl}$ adalah 1:20 (w/v). Sampel kitin dan $\mathrm{HCl}$ dicampur kedalam gelas beaker dan dilakukan pengadukan dengan pemanasan dengan suhu $80-100^{\circ} \mathrm{C}$. Filtrat kemudian didinginkan dan disaring lalu dibilas dengan akuades hingga $\mathrm{pH}$ netral. Filtrat lalu dikeringkan dalam oven dengan suhu $80^{\circ} \mathrm{C}$ selama 24 jam.

Penentuan derajat deasetilasi dilakukan dengan metode titrasi potensiometri linier yang diusulkan oleh Jia dan Shen, (2002). Sebanyak 0,1 g kitosan dilarutkan kedalam $30 \mathrm{~mL}$ $\mathrm{HCl} 0,1 \mathrm{M}$, dan kemudian dititrasi dengan $\mathrm{NaOH} 0,1 \mathrm{M}$. Total $\mathrm{NaOH}$ yang diperlukan dalam titrasi digunakan sebagai variabel perhitungan derajat deasetilasi. Persamaan dalam perhitungan derajat deasetilasi kitosan dapat dilihat pada persamaan dibawah ini:

$$
\mathrm{DD}(\%)=\frac{\left(\mathrm{C}_{1} \mathrm{~V}_{1}-\mathrm{C}_{2} \mathrm{~V}_{2}\right)}{\mathrm{M} \times 0,0994} \times 0,016
$$

Keterangan :

$\mathrm{C}_{1}$ : konsentrasi larutan standar $\mathrm{HCl}$

$\mathrm{C}_{2}$ : konsentrasi larutan standar $\mathrm{NaOH}$

$\mathrm{V}_{1}$ : volume larutan $\mathrm{HCl}$ yang digunakan

$\mathrm{V}_{2}$ : volume larutan $\mathrm{NaOH}$ untuk titrasi

$\mathrm{M}$ : massa kitosan

Kitosan yang diperoleh selanjutnya diuji aktivitasnya pada pengolahan air gambut. Kitosan disuspensikan ke dalam air gambut dengan perbandingan 1:20 (w/v). Suspensi tersebut diaduk dengan kecepatan 100 rpm selama 20 menit pada suhu kamar kemudian kecepatan pengadukan diperlambat hingga $50 \mathrm{rpm}$. Proses dihentikan pada menit ke 60 dan larutan dibiarkan selama 60 menit hingga terjadi pengendapan. Endapan yang terbentuk dipisahkan, dan larutan sisa dilakukan analisis keasaman $(\mathrm{pH})$, total padatan terlarut (TDS), Warna air, dan Kandungan zat organik.

\section{HASIL DAN PEMBAHASAN}

Kitosan merupakan turunan utama dari kitin. Kitosan diperoleh dari proses deasetilasi kitin menggunakan basa konsentrasi tinggi. Reaksi konversi kitin menjadi kitosan secara skematik dapat dilihat pada gambar 1. Semakin banyak gugus asetil pada kitin yang dilepaskan, maka semakin tinggi nilai DD yang terukur. Dengan demikian semakin baik kualitas kitosan yang dihasilkan. Lepasnya gugus asetil meninggalkan gugus amina pada backbone polimer. Gugus amina yang bersifat relatif lebih polar dibandingkan gugus asetil, menyebabkan kitosan lebih mudah larut dalam air jika dibandingkan dengan kitin. Kitosan dengan nilai DD yang tinggi mutlak diperlukan guna mendapatkan kepolaran tinggi sehingga diharapkan dapat berinteraksi lebih efektif dengan senyawa-senyawa humat yang terlarut dalam air gambut. 

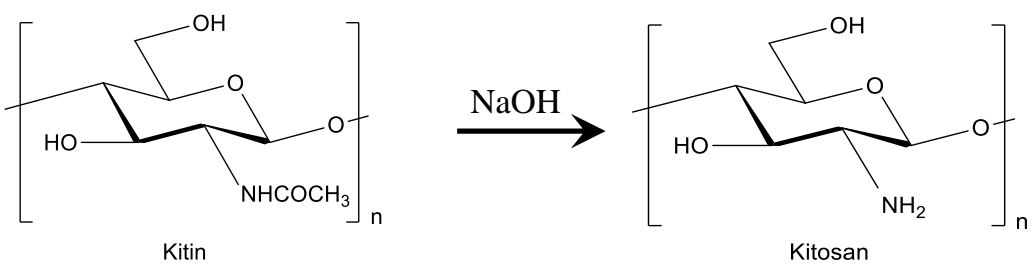

Gambar 1. Deasetilasi pada konversi kitin menjadi kitosan

Gambar 2 menyajikan informasi mengenai pengaruh konsentrasi basa $\mathrm{NaOH}$ terhadap DD yang dihasilkan. Dari grafik tersebut dapat dilihat semakin tinggi konsentrasi $\mathrm{NaOH}$ yang digunakan maka akan semakin tinggi pula DD yang diperoleh. Penggunaan $\mathrm{NaOH}$ $70 \%$ menghasilkan DD hampir mencapai 90\%. Penggunaan $\mathrm{NaOH}$ dengan konsentrasi lebih tinggi untuk mendapatkan DD yang lebih baik tidak disarankan dalam penelitian ini, karena berkenaan dengan efisiensi bahan. Optimasi waktu atau suhu deasetilasi lebih dianjurkan untuk mendapatkan nilai DD yang lebih baik. Selanjutnya kitosan hasil deasetilasi menggunakan $\mathrm{NaOH} 70 \%$ inilah yang digunakan sebagai koagulan pada air gambut.

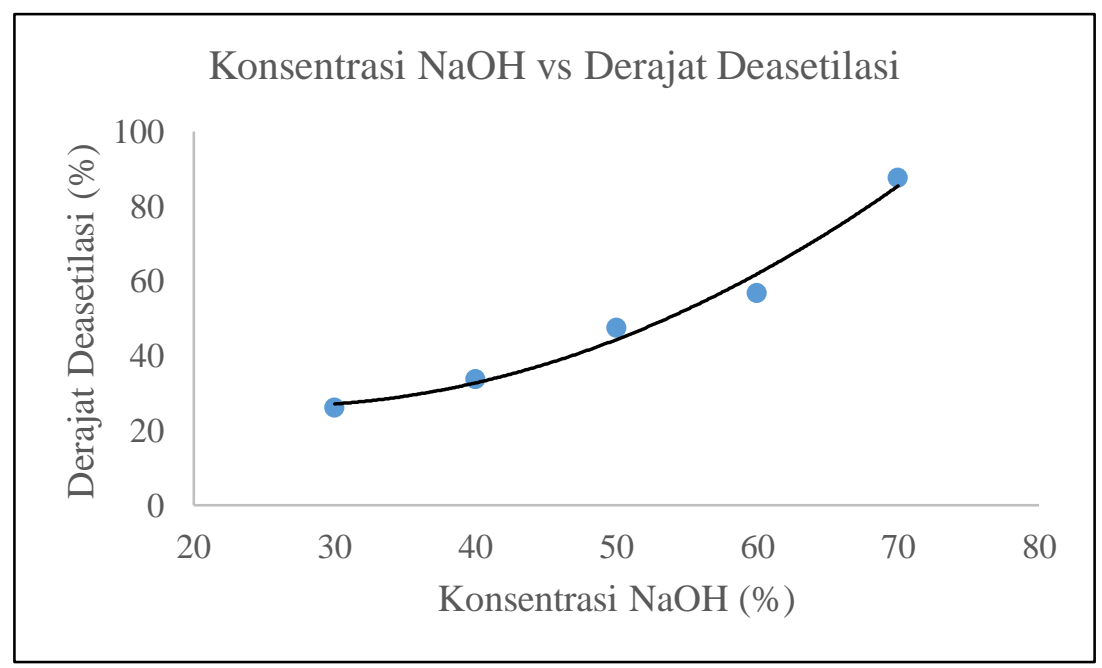

Gambar 2. Pengaruh Konsentrasi $\mathrm{NaOH}$ terhadap derajat deasetilasi kitosan cangkang udang putih

Informasi mengenai aktivitas kitosan cangkang udang putih terhadap air gambut disajikan pada tabel 1. Beberapa parameter yang dijadikan acuan di antaranya adalah warna, total padatan terlarut (TDS), keasaman $(\mathrm{pH})$ dan kandungan zat organik. Warna merupakan salah satu indikator kualitas air. Analisis warna pada sampel air gambut dapat memberikan informasi kualitas air gambut tersebut. Analisis warna pada sampel air gambut sebelum dan sesudah diproses menggunakan kitosan cangkang udang putih, dapat menjadi indikator aktivitas kitosan terhadap peningkatan kualitas air gambut.

Sebelum ditambahkan kitosan, nilai warna pada air gambut sebesar $1947 \mathrm{PtCo}$, dan setelah ditambahkan kitosan cangkang udang putih nilai tersebut turun menjadi 1610 PtCo. Penurunan warna ini sangat ditentukan oleh proses koagulasi dan flokulasi antara partikel-partikel humat di air gambut dengan kitosan. Partikel humat diketahui sebagai partikel yang memberikan warna merah kehitaman pada air gambut. Semakin tinggi konsentrasi partikel humat maka semakin pekat warna air gambut. Penurunan warna sebesar $17,3 \%$ ini mengindikasikan sebagian senyawa humat mengalami koagulasi dengan kitosan. 
Tumbukan antara partikel humat dengan kitosan pada putaran pengadukan cepat memicu terjadinya proses koagulasi yang merupakan interaksi elektrostatik antara sifat polikationik kitosan dengan sisi-sisi negatif partikel humat. Partikel humat terkoagulasi kitosan yang terbentuk merupakan inti flok. Flok-flok yang lebih besar terbentuk ketika inti-inti flok berukuran kecil beraglomerasi pada putaran pengadukan lambat, hingga mencapai ukuran cukup besar yang mampu ditarik gravitasi bumi untuk proses pengendapan. Berkurangnya konsentrasi partikel humat setelah sebagian mengalami pengendapan diindikasikan dengan berkurangnya nilai derajat warna dari $1947 \mathrm{Pt}$-Co menjadi $1610 \mathrm{Pt}-\mathrm{Co}$.

Tabel 1. Aktivitas kitosan pada pengolahan air gambut

\begin{tabular}{ccccc}
\hline \multirow{2}{*}{ No. } & \multirow{2}{*}{ Parameter } & \multirow{2}{*}{ Satuan } & \multicolumn{2}{c}{ Treatment } \\
\cline { 4 - 5 } & & & Sebelum & Setelah \\
\hline 1 & Warna & PtCo & 1947 & 1610 \\
2 & TDS & mg/L & 264 & 2981 \\
3 & pH & - & 5,9 & 7,9 \\
4 & Zat Organik & mg/L & 364 & 354 \\
\hline
\end{tabular}

Kondisi analisis: Warna diukur dengan metode spektroskopi UV-Vis, TDS diukur dengan metode konduktometri, $\mathrm{pH}$ dianalisis menggunakan $\mathrm{pH}$ meter, zat organik diidentifikasi menggunakan metode titrimetri permanganat.

Total padatan terlarut baik itu padatan organik maupun anorganik diekspresikan dengan data TDS. Kuantitas padatan terlarut dapat diidentifikasi menggunakan metode konduktometri. Di dalam air gambut, konsentrasi padatan terlarut merupakan konsentrasi senyawa-senyawa humat yang terlarut dalam air. Dari hasil pengukuran, terjadi peningkatan nilai TDS sebelum dan sesudah penambahan kitosan yakni berturut-turut 364 mg/L menjadi $2981 \mathrm{mg} / \mathrm{L}$. Berdasarkan analisis warna, dengan berkurangnya derajat warna maka seharusnya konsentrasi senyawa-senyawa humat juga berkurang di dalam air. Namun data TDS menunjukkan peningkatan konsentrasi padatan terlarut. Peningkatan nilai TDS ini diduga sebagai akibat dari penggunaan kitosan berlebih. Penggunaan kitosan berlebih menyebabkan larutnya sebagian kecil kitosan ke dalam air gambut. Kitosan dengan derajat deasetilasi tinggi yang berarti memiliki kuantitas gugus amina relatif banyak, berakibat pada peningkatan sifat polar pada kitosan. Dengan demikian, semakin tinggi derajat deasetilasi maka semakin mudah bagi kitosan untuk tersuspensi dan larut dalam pelarut polar.

Selain itu, proses demineralisasi yang tidak sempurna pada proses isolasi kitin menyebabkan masih terdapatnya mineral di sekitar kitosan dalam jumlah besar. Mineralmineral ini dapat lepas atau larut ke dalam air menjadi ion-ion logam positif pada saat proses aplikasi kitosan. Mineral-mineral yang lepas memberikan kontribusi meningkatnya jumlah padatan terlarut yang diekspresikan dengan tingginya nilai TDS.

Nilai $\mathrm{pH}$ yang rendah pada air gambut disebabkan karena tingginya konsentrasi asam humat dan asam fulvat yang merupakan komponen utama senyawa humat pada air gambut. Proses koagulasi dan flokulasi dengan kitosan diharapkan dapat menurunkan konsentrasi asam humat dan fulvat tersebut. Berkurangnya konsentrasi asam ditandai dengan naiknya $\mathrm{pH}$ sebelum dan sesudah perlakuan, yakni berturut-turut dari $\mathrm{pH} 5,9$ menjadi 7,9 . 
Pada akhir perlakuan dengan kitosan, nilai $\mathrm{pH}$ berada pada daerah basa yakni $\mathrm{pH}$ 7,9. Hal ini sesuai dengan fakta bahwa nilai TDS meningkat. Nilai TDS meningkat diperkirakan karena larutnya mineral yang tersisa di sekitar molekul kitosan. Secara umum diketahui bahwa kandungan mineral dalam cangkang udang putih sebesar antara 45 - 50\% dengan kalsium karbonat $\left(\mathrm{CaCO}_{3}\right)$ sebagai komponen utamanya. $\mathrm{CaCO}_{3}$ merupakan garam yang bersifat basa jika larut dalam air karena garam ini berasal dari basa kuat $\mathrm{Ca}(\mathrm{OH})_{2}$ dan asam lemah $\mathrm{H}_{2} \mathrm{CO}_{3}$. Dengan demikian, larutnya $\mathrm{CaCO}_{3}$ menyebabkan peningkatan nilai $\mathrm{pH}$ ke arah basa.

Hasil uji kandungan zat organik pada air gambut menunjukkan terjadinya penurunan jumlah zat organik setelah perlakuan dengan kitosan sebesar $10 \mathrm{mg} / \mathrm{L}$. Meskipun angka penurunannya tidak terlalu besar, namun hal ini sesuai dengan fakta menurunnya derajat warna seperti yang telah dijelaskan di atas. Pada dasarnya, jika senyawa-senyawa humat yang merupakan senyawa organik mengalami koagulasi dan flokulasi dengan kitosan, maka nilai konsentrasi kandungan zat organik juga akan menurun. Penurunan parameter zat organik yang kecil disebabkan karena larutnya sejumlah tertentu kitosan ke dalam air. Kitosan yang merupakan senyawa organik, jika tertinggal atau larut dalam air akan berkontribusi meningkatkan jumlah zat organik yang terdeteksi.

\section{PENUTUP}

Konsentrasi basa $\mathrm{NaOH}$ yang digunakan pada proses deasetilasi kitin menjadi kitosan sangat berpengaruh pada nilai derajat deasetilasi yang diperoleh. Semakin tinggi konsentrasi basa yang digunakan maka semakin tinggi nilai derajat deasetilasi kitosan. Pada variasi konsentrasi $\mathrm{NaOH} 30-70 \%$, derajat deasetilasi kitosan tertinggi diperoleh ketika menggunakan $\mathrm{NaOH} 70 \%$ sebesar $87,5 \%$. Aktivitas kitosan terhadap air gambut Kalimantan Barat menunjukkan bahwa telah terjadi proses koagulasi dan flokulasi komponen-komponen humat. Hal ini dibuktikan dengan menurunnya nilai parameter warna dari 1947 PtCo menjadi 1610 PtCo yang sebanding dengan penurunan konsentrasi komponen humat. Proses koagulasi - flokulasi ini diperkuat dengan menurunnya parameter nilai kandungan zat organik dari $364 \mathrm{mg} / \mathrm{L}$ menjadi $354 \mathrm{mg} / \mathrm{L}$. Berkurangnya konsentrasi asam di air gambut seperti asam humat dan asam fulvat, menyebabkan meningkatnya nilai $\mathrm{pH}$. Kandungan TDS yang meningkat kemungkinan disebabkan karena melarutnya sisa-sisa mineral yang masih terkandung dalam kitosan.

\section{DAFTAR PUSTAKA}

Ariyani, D., Santoso, U. T., Nurmasari, R., Irawati, U., Iriansyah, 2015, Synthesis of glutaraldehyde crosslinked superporous chitosan with polyvinyl alcohol addition for peat water humic acid adsorption, Journal of wetlands environmental management, 3, 2, $79-89$

Bigogno, R. G., Rodriguez, R. J. S., Abreu, M. F., 2018, Quaternized chitosan for ecological treatment of bauxite mining effluents, J. Polym. Environ.

Brugnerotto, J., Lizardi, J., Goycoolea, F. M., Argüelles-Monal, W., Desbrières, J., Rinaudo, M., 2001, An infrared investigation in relation with chitin and chitosan characterization, Polymer, 42, 3569 - 3580

de Moura, C. T., de Moura, J. M., Soares, N. M., de Almeida Pinto, L. A., 2011, Evaluation of molar weight and deacetylation degree of chitosan during chitin deacetylation reaction: used to produce biofilm, Chem. Eng. Process., 50, 351 355 
Jia, Z., Shen, D., 2002, Effect of reaction temperature and reaction time on the preparation of low-molecular-weight chitosan using phosphoric acid, Carbohydr Polym., 49, $393-396$

Knorr, D., 1982. Function Properties of Chitin and Chitosan. J. Food Sci., 47, 2: $593-$ 595

Santoso, U. T., Rodiansono, Junaidi, A. B., Umaningrum, D., 2015, Synthesis of chitosan-coated magnetic microparticle using glutaraldehyde as crosslinker and PEG as spacer arm and its application as adsorbent of peat humic acid, Journal of wetlands environmental management, 3, 1, $22-27$

Türker, O. C., Baran, T., 2017, Evaluation and application of an innovative method based on various chitosan composites and Lemma gibba for boron removal from drinking water, Carbohydr. Polym., 166, $209-218$

Wetland International, 2004, Peta sebaran lahan gambut, luas dan kandungan karbon di pulau Kalimantan, Wetland International - Indonesia Programme, Bogor, Indonesia

Zulfikar, M. A., Setiyanto, H., Wahyuningrum, D., Mukti, R. R., 2014, Peat water treatment using chitosan-silica composite as an adsorbent, Int. J. Environ. Res., 8, $3,687-710$ 